\title{
THE USE OF LEXICAL COLLOCATIONS IN SOME ARTICLES ON SEVENTEEN.COM WEBSITE
}

\author{
Marsya Aprila Tayibnapis ${ }^{1}$, Lina Meilinda ${ }^{2}$, and Yessy Purnamasari ${ }^{3}$ \\ marsya.aprila.bing18@polban.ac.id ${ }^{1}$ \\ lina.meilinda@polban.ac.id ${ }^{2}$ \\ yessy.purnamasari@polban.ac.id ${ }^{3}$
}

Politeknik Negeri Bandung

\begin{abstract}
Collocation is one of the problems faced by EFL (English as a Foreign Language) learners when learning English because they neither have rules nor reasons behind their existence, and the EFL Learners may get confused about the right collocations to use. For that reason, this study is aimed to find the use of lexical collocations and their meaning. This study used descriptive qualitative research. The data were analysed based on the collocations' theory proposed by Benson et al. (2010). The source of data is eleven articles from eight sections on the seventeen.com website. The result of the study reveals that there were 79 lexical collocations and they were classified as six out of seven types. The data showed that the most used type is L3 (adjective + noun) and the least used is L4 (noun + verb). To get a deeper comprehension of the lexical collocation found in the articles, the meanings of the collocations are explained. The way to know the meaning is by understanding the contexts. In short, there are 79 lexical collocations found in some articles on the seventeen.com website and the meaning of them are defined based on their contexts.
\end{abstract}

Keywords: Collocations, Lexical Collocations, Seventeen.com, EFL Learners, Meaning from Context

\section{INTRODUCTION}

Vocabulary is an essential thing to learn in the English language. When it comes to learning about vocabulary, people tend to memorize words as much as they can. With the development of the range of vocabulary, numerous issues emerge concerning the proper utilization of words in a context, among which is collocation. Nevertheless, students of English are more concerned about how to grow their vocabulary to extend the number of words they can keep in mind (Duan \& Qin, 2012). Knowing words and their meanings by themselves is not enough. Words are associated with a context. The context and intentional association, which include collocations, offer connections that assist learners in deeply understanding the meaning of words and adding it to his or her current vocabulary. The method to learn words by collocations teaches learners to use the correct words at the correct moment while providing an idea to remember new words (Duan \& Qin, 2012). 
Collocation can be defined as a couple or group of words frequently used together (McCarthy \& O'Dell, 2005). These combinations of words are used by English native speakers in their daily communication and they make the language sound natural. However, non-native English speakers or EFL (English as a Foreign Language) learners need more effort to use the right collocations. Many ways can be conducted to improve the EFL learners' competence in using collocations such as reading English texts, reading books about collocations, and listening to how native speakers use collocations. Furthermore, if the EFL learners want to get a better understanding of collocations, they can study by reading some research about collocations. Therefore, this study is conducted based on several reasons below.

First, learning collocations are important. There are several reasons why it is important as stated by McCarthy (2018). In the first place, research has appeared that comprehension of collocations could be a great sign of common ESL (English as a Second Language) capability. Also, he adds that acquiring collocations is an essential part of competence within the target language. Moreover, fluency depends on being able to deliver combinations of words naturally. Thus, mastering collocations is essential to become fluent in English. Besides those reasons, collocations are essential since they make your language sound more natural. If you master collocations, your English becomes more idiomatic like the way native speakers speak it (Luis, 2019). An example of a common collocation is fast food. If we change it with quick food, it will sound weird. Another example is strong coffee, not powerful coffee. Therefore, the more we know about many kinds of collocations, the better our language is.

Second, collocations can be alternative ways to say something. As stated by McCarthy \& O’Dell (2005), using collocations to say something can make it more colourful or more exact. By knowing to use many alternative words, the style of writing can be improved. Also, collocation adds a nice flavour to one's speech when speaking (Galal, 2015). For example, you can say pitch dark and bitterly cold instead of very dark and very cold (McCarthy \& O'Dell, 2005).

Third, collocations help EFL learners to think faster and communicate more effectively. Most of the spoken or written English texts contain collocations. Hills (2000, as cited in Ashiyan \& Salehi, 2016) said it is approximated that more than $70 \%$ of a person's conversations in speaking, hearing, reading, or writing are composed of different forms of fixed expressions. Due to this reason, EFL learners must study the fixed expressions such as collocations because they are always used in many aspects of English. If someone is already used to using collocations, it will make them communicate better.

Last, there are some causes to learn lexical collocations for EFL learners and non-native English speakers. Benson et al. (2010) divided collocations into two major groups: grammatical collocations and lexical collocations. Among these two groups, Yan (2010) concludes the right lexical collocations for different language situations are more important than the grammar structure. Yan also points out that lexical collocations may be easy to predict for people living in English-speaking countries, the collocated words arise spontaneously when the main words appear, yet they are unforeseeable for language learners. Hence, this study's focus is lexical collocations.

From the four positive reasons about learning collocations, there are some problems related to collocations. Collocations are one of the problems faced by EFL learners when 
learning the English language. Luis (2019) explains that collocations are abstract, usually do not have an explanation, and also the list is limitless. If we inquire of a native speaker about the reason for using certain collocations, they will not be able to give us an explanation other than "I just do" or "It sounds right" (Common Collocation Problems for EFL Learners, 2017). Another problem is there has been no definite guidance for non-native learners to determine which combinations are precisely appropriate and whose co-occurrence is highly predictable; or which ones are potentially appropriate for creative purposes, and which are utterly inappropriate (Rini $\&$ Moehkardi, 2002). It means that collocation has no rigid and specific rules that allow the learners to use it systematically.

As the data source of analysis, seventeen.com is the website in which the texts are used to be identified from the scope of collocations. This website publishes articles related to teenagers. There are several factors why it was chosen as the data source. First, all of the contents of this website are written in English. Besides, there are many kinds of articles in it. From the articles in it, not only can we learn about collocations used in them but we can also add more knowledge from various categories. Also, because it is intended for teenagers, the language used is easy to understand and the topic for each article is suitable for youth. Those are the reasons for conducting the study. It is important for EFL learners and non-native speakers to master collocations to improve their fluency in English.

From the background above, this analysis has aims to identify the type of lexical collocations used in some articles of the seventeen.com website and to describe the meaning of lexical collocations found in some articles of the seventeen.com website.

To conduct this study, a literature review is needed to get a deeper understanding of similar previous studies and find gaps between the previous studies and this study. The first source is an undergraduate thesis by Putri (2018) entitled An Analysis of Collocations Used in Written Assignment. The researcher aims to find out the types of collocations that students dominantly make mistakes in writing assignments and to discover the students' strategies in solving the problem in understanding collocation. The study uses qualitative research. The result shows the mistakes about collocations in the students' writing that are classified into three types: verb + noun, adjective + noun, and verb + adverb. Besides, analysing the students' mistakes, she also interviews the students about how they solve the problem of understanding collocations. The students said they solve the problem by reading a book/dictionary, asking the lecturer, and exploring much information about collocation itself.

The second source is an undergraduate thesis by Rakhmawati (2017) entitled Lexical Collocation in The Jakarta Post Newspaper. The researcher aims to describe what types of lexical collocations are presented in the newspaper, and also to describe and to get an explanation of the usage of lexical collocation in the newspaper. The method to do this research is content analysis. Through this research, she finds that the newspaper provides six out of seven types of lexical collocation, they are verb(active) + noun, adjective + noun, noun + verb, noun + noun, adverb + adjective or adjective + adverb, and adverb + verb. Besides, the result of this study shows the usage of lexical collocation based on different kinds of articles is different.

The last source is an undergraduate thesis by Gayatri (2018) entitled An Analysis of Collocation in Hillary Clinton's Speech. The researcher aims to discuss the types of collocations and the most dominant collocation type used in Hillary Clinton's Speech. The research method 
applies qualitative descriptive. From this study, she finds out six out of eight grammatical collocations used in the speech, there are also seven types of lexical collocation used in the speech, and the most dominant type is grammatical collocation.

From all the previous studies above, the gap can be seen between the previous studies and this study. This study uses articles from a website while the previous studies use written assignments, a newspaper, and a speech. Besides, the previous studies do not discuss the meaning of the collocations that are found in their research; therefore, this study explains the meaning of the collocations based on the context of the subject. By explaining the meaning of the collocations, this study is expected to help the EFL learners and non-native English speakers to understand using the collocations

\section{THEORETICAL FRAMEWORK}

The first theory is definitions of collocation. Collocation can be defined as the strategy by which words in a language combine to create natural-sounding speech and writing (McIntosh et al., 2002). Collocation also refers to a couple or group of words frequently used together (McCarthy \& O'Dell, 2005). Besides, Oliveira (2013) defined collocation as the typical or common combinations of words we use together. An example of a collocation is doing homework. If someone says make homework it is still understandable but it is not commonly used. Another example is making a mistake. It is uncommon for someone to say doing a mistake. In short, collocation is a couple of words that are often used together to create natural utterances.

The second theory is the types of lexical collocations. Benson et al. (2010) divide collocations into two major groups: grammatical collocations and lexical collocations. A grammatical collocation refers to a phrase made up of a predominant word (noun, adjective, or verb) and a preposition or grammatical structure like an infinitive or clause (Benson et al., 2010). In contrast, lexical collocations ordinarily do not contain prepositions, infinitives, or clauses. Commonplace lexical collocations comprise nouns, adjectives, verbs, and adverbs (Benson et al., 2010). Lexical collocation can be divided into seven types described in the table below.

Table 1. Type of Lexical Collocations

\begin{tabular}{|c|c|c|c|c|}
\hline Type & Description & Formula & Example & \\
\hline $\mathrm{L} 1$ & $\begin{array}{l}\text { L1 consists of a } \\
\text { verb (usually } \\
\text { transitive) and a } \\
\text { noun/pronoun } \\
\text { (or prepositional } \\
\text { phrase). }\end{array}$ & $\begin{array}{l}\text { Verb }+ \\
\text { noun/pronoun }\end{array}$ & $\begin{array}{l}\frac{\text { Compose }}{\text { music }} \\
\text { verb } \\
\text { noun }\end{array}$ & + \\
\hline L2 & $\begin{array}{l}\text { L2 consists of a } \\
\text { verb meaning } \\
\text { essentially } \\
\text { eradication } \\
\text { and/or } \\
\text { nullification and } \\
\text { a noun. }\end{array}$ & Verb + noun & $\frac{\text { Reject }}{\frac{\text { appeal }}{\text { verb }}}+$ & $\begin{array}{l}+\quad \underline{\text { an }} \\
\text { noun }\end{array}$ \\
\hline
\end{tabular}

Copyright (C2021 JOEPALLT

Journal of English Pedagogy, Linguistics, Literature, and Teaching 
L3

L4

L5

L6

L7
L3 consists of an adjective and a noun.

L4 consists of a noun and verb.

L5 consists of the unit that is associated with a noun (usually noun $_{1}$ of noun 2 )

L6 consists of an adverb and an adjective. verb and an adverb.

Adjective + noun

Noun + verb

Noun + noun

Adverb + adjective

Verb + adverb $\frac{\text { Strong }}{\text { adj }}+\frac{\text { tea }}{\text { noun }}$

$\frac{\text { Bees }}{\text { noun }}+\frac{\text { buzz }}{\text { verb }}$

$\frac{\text { A bouquet of }}{\text { flowers }}$
noun
noun

$\underline{\text { Hopelessly }}+\underline{\text { addicted }}$ adverb adj

$\frac{\text { Affect }}{\text { verb }}+\underline{\text { deeply }}$
adverb

As described in the table, seven types of lexical collocations are named as L1 to L7. The types make combinations from nouns, adjectives, verbs, and adverbs. All of them are used for categorizing the lexical collocations found in this study.

The last theory is how to get the meaning of a word in context. Besides searching for collocations in the articles, this study also finds the meaning of each collocation. There is a way to know the meaning of words in a context. By knowing the meaning of words, it is easier to understand the use of collocations.

According to Roell (2020), the way to understand the meaning of words is using context clues. A new vocabulary term can be understood by using only the context around it. She also stated that an unknown vocabulary word shows its meaning by referring to the elements of a passage. You never have to memorize every word for this reason-you just have to keep in mind to use contextual hints. So, it is better to look at the whole context of a passage to interpret words that we do not know their meanings. For instance, there is a sentence "Michael shows animosity to one of the city mayor candidates by disturbing his campaign, ruining his posters in public places, and spreading bad rumours about him." You may not understand the word animosity by itself, but if you look at the context of the full sentence, you will get information to help you define the word. The actions of Michael toward one of the city mayor candidates are annoying. By knowing his actions, the word animosity can be interpreted as hatred.

There is a strategy for guessing the meaning of words from context stated by Clarke and Nation (1980). The strategy has four steps. First, deciding the words' part of speech. Second, seeing the immediate grammar. The unknown words may have positive and negative values and it depends on the context of the text. Third, learning the board context. The predictable patterns that support language areas like cause and effect, condition, contrast, classification, or exemplification can be used to guess the meaning. Last, guessing the word and checking the guess. There are three methods for checking: 1) look over the part of speech of the meaning that has been guessed is the same as the word in the text, 2) See if a word contains a prefix, suffix, or 
root as the indication of the meaning, 3) Replace the guess with the word in the text and see if it makes sense. This strategy is useful for knowing the meaning of combination words (collocations) that are found in this analysis.

\section{METHOD}

The method that is used for this study is qualitative research. According to Palmer and Bolderston (2006), qualitative research is an interpretive technique that uses the subjective perspectives of participants to gain insight into the particular meanings and behaviours encountered in a social phenomenon. The purpose of using qualitative research is to describe the result of the research in descriptive form.

Qualitative research has several designs, one of them is qualitative descriptive research. Qualitative descriptive refers to the descriptive description in qualitative research (Kim et al., 2017). This design aims to provide a comprehensive summary of specific events experienced by individuals or groups of individuals in everyday terms (Lambert \& Lambert, 2013). Due to the aim of qualitative descriptive, this study also analyses something related to everyday terms, in this case, collocations.

In this study, the subject that is used is lexical collocations found in some articles from the seventeen.com website. The data are obtained from eleven articles provided by the website. There are several criteria for getting the source of data. First, the articles are taken from the eight sections of articles on the website. Second, the articles that are used were published from January to April 2021. Last, to get almost equal subjects, the articles used are one of the articles from each section that has about 400-600 words. Nevertheless, some sections tend to have more pictures rather than text. This case makes the articles tend to have less than 400 words. To resolve it, two articles consisting of 200-300 words are used to replace an article with 400-600 words.

The way to collect the data for this study is by doing document analysis. Document analysis can be defined as a methodical approach to review or evaluate documents, both printed and electronic (computer-based and Internet-based) data (Bowen, 2009). This method is used to find the collocations in some articles on the seventeen.com website. The steps of collecting data: 1) opening the sections on the website, 2) choosing some articles, 3) saving the articles, 4) analysing the sentences in the articles, 5) Marking the words presumed as lexical collocations, 6) collecting the lexical collocations found in the articles.

There are some steps in analysing the collocations found in the articles of seventeen.com website. First, make sure that all of the data are included in the types of lexical collocations. For instance, there is a collocation dark skin. It is a combination of adjective + noun. Then, this combination is included in the L3 type of lexical collocations. Second, find the meaning of all lexical collocations found in the articles by their contexts. For example, the collocation of dark skin in the context describes the physical appearance of someone. Then, the meaning of this collocation is a type of human skin colour that is close to black. Third, write all of the findings in tables to make them look well organised. Last, conclude the analysis. After analysing all of the data, the data are written in the findings and discussion. This contains the results of the analysis such as what types of lexical collocations are found in the articles and their meanings. It also contains a discussion about the findings of the analysis. 


\section{FINDINGS AND DISCUSSION}

In analysing the data, this study uses the collocations theory by Benson et al. (2010) that divided collocations into two major groups: grammatical collocations and lexical collocations. This study only discusses lexical collocations. The lexical collocations can be classified into seven types. The results of types of lexical collocations that are found in eleven articles of seventeen.com website are shown in the table below.

Table 2. The results of the analysis

\begin{tabular}{|c|c|c|}
\hline No. & Type of lexical collocations & Amount \\
\hline 1. & L1 (verb + noun/pronoun) & 20 \\
\hline 2. & L3 (adjective + noun) & 40 \\
\hline 3. & L4 (noun + verb) & 1 \\
\hline 4. & L5 (unit that is associated with a noun + noun) & 7 \\
\hline 5. & L6 (adverb + adjective) & 3 \\
\hline \multirow[t]{2}{*}{6.} & L7 (verb + adverb) & 8 \\
\hline & Total & $\begin{array}{l}79 \\
\text { Collocations }\end{array}$ \\
\hline
\end{tabular}

The table above shows the results of the lexical collocations found in some articles on the seventeen.com website. There are six out of seven types of lexical collocations, and the total collocations that are found are 79 collocations. Some collocations have been used more than once in an article, but the results are counted as just one of them.

\section{LEXICAL COLLOCATIONS FOUND IN SOME ARTICLES OF SEVENTEEN.COM}

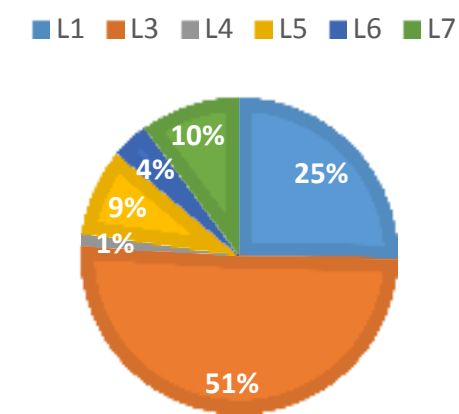

Figure 1. The results of lexical collocations

The pie chart above shows the amount of lexical collocations types that are found. It is presented that L3 collocations are the most used and L4 is the least used type. Meanwhile, L2 collocations cannot be found in the articles, so it is not included in the results. The list below is the samples of lexical collocations found in the articles.

1. L1 (verb + noun/pronoun)

The finding shows twenty lexical collocations L1 (verb + noun/pronoun). Three of the data are explained as samples.

a. Spend time

The word spend is a verb collocated with a noun that is time. 
b. Win award

The word win is a verb collocated with a noun that is award.

c. Take picture

The word take is a verb collocated with a noun that is picture.

2. $\mathbf{L 3}$ (adjective + noun)

The finding shows forty lexical collocations L3 (adjective + noun). Three of the data are explained as samples.

a. Pop star

The adjective word pop is collocated with the noun word star.

b. Last time

The adjective word last is collocated with the noun word time.

c. Good trip

The adjective word good is collocated with the noun word trip.

3. L4 (noun + verb)

The finding shows one lexical collocation L4 (noun + verb) that is eye(s) roll. It is a combination of the noun word eye with the verb word roll.

4. L5 (noun + noun)

The finding shows seven lexical collocations L5 (noun + noun). Three of the data are explained as samples.

a. Group photo

The word group is a noun collocated with another noun that is photo.

b. Thrift shop

The word thrift is a noun collocated with another noun that is shop.

c. Fashion retailer

The word fashion is a noun collocated with another noun that is retailer.

5. L6 (adverb + adjective)

The finding shows three lexical collocations L6 (adverb + adjective).

a. Brand new

The word brand is an adverb collocated with an adjective word new.

b. Each other

The word each is an adverb collocated with an adjective word other.

c. Pretty good

The word pretty is an adverb collocated with an adjective word good.

6. L7 (verb + adverb)

The finding shows eight lexical collocations L7 (verb + adverb). Three of the data are explained as samples.

a. Look away

The word look is a verb collocated with an adverb word away.

b. Bow down

The word bow is a verb collocated with an adverb word down.

c. Invite over

The word invite is a verb collocated with an adverb word over. 
It can be concluded that L3 (adjective + noun) is the most used type because the articles are descriptive text and the context of the articles have themes related to lifestyle. In this kind of article, adjective + noun is mostly used to describe things. On the other hand, the least used is L4 (noun + verb). It is the least used because the verb in this type of collocation is used as an action characteristic of the noun, but the character of person or thing in the articles already described by adjective + noun.

After the types of lexical collocations are found, the meanings of each lexical collocations are also being analysed. The meanings of those collocations are based on their context in the articles. The list below shows some samples of the total data.

1. Spend time

"It's likely Pete is spending time with Phoebe before she heads back to Bath, England to start filming season 2 of the hit Netflix series, Bridgerton."

The sentence above shows the context of collocation spend time. The context describes there is a person (Pete) who is doing an activity or more with another person (Phoebe) before this person is going back to work. Therefore, spend time can be defined as accompanying someone for leisure.

2. Win award

"Billie Eilish and Finneas won the award for their Bond theme track, "No Time to Die"."

The sentence above shows the context of collocation win award. The context describes that two people get a prize for their work or creation. Therefore, winning an award can be defined as getting a prize for something that somebody has done.

3. Take picture

"It looks like it's Pete's turn to visit Phoebe as he's been seen out and about in Altrincham, Greater Manchester with a group of coffee lovers taking a pic of him at their local cafe."

The sentence above shows the context of collocation: take picture. The context describes that some people are keeping a moment of other people in a photo form. Therefore, taking picture can be defined to capture an image using a camera.

4. Pop star

"Celebrating the release of her new EP, the pop star made a rare (heh) appearance on IG Stories to gush about her new music."

It is presented that the sentence above contains a collocation, pop star. The collocation pop star in the context above describes that pop star is referring to a person. This person is someone who is working in the music industry. So, the meaning of pop star is a well-known and successful pop singer or performer.

5. Last time

"This might be the last time we see her performances during her Folklore and Evermore era as she prepares to release re-recordings of her previous albums, starting off with Fearless."

It is presented that the sentence above contains a collocation, last time. The collocation last time in the context above describes that she will not perform again during a period of time. Then, it can be defined as the final time.

6. Good trip 
"Don't get me wrong-I love a good trip to Zara, but for me, there's no better feeling than emerging from the packed aisles of a second-hand shop with a tote bag full of one-of-a-kind treasures."

It is presented that the sentence above contains a collocation, good trip. The collocation good trip in the context above describes that the writer is enjoying going shopping in Zara. Then, it can be defined as a pleasant visit to a particular location.

7. Eye(s) roll

"Ngl, when I first heard the news, my eyes rolled for several minutes-the last thing the beauty world needs is another nonsensical, money-grab makeup launch."

The sentence above shows the context of the collocation eye(s) roll. The context describes that the writer feels weird when the writer heard the news. Thus, eye(s) roll meaning is the action or gesture by turning your eyes as a way of expressing annoying, exasperating, unbelieving feelings.

8. Group photo

"The trio even posed for a group photo after their performance that you can check out below:"

The sentence above shows the context of a group photo. The context describes doing an action to keep memories in a photo form. Thus, group photo meaning is several people taking a picture together using a camera.

9. Thrift shop

"Thrift shops are often more affordable than fast-fashion retailers, they stock more diverse inventory, and they provide a no-waste shopping experience you can enjoy guilt-free."

The sentence above shows the context of collocation thrift shops. The context describes that a thrift shop has several advantages as a place to shop. Thus, thrift shop meaning is a shop that sells used goods at a discounted price.

10. Fashion retailer

"Thrift shops are often more affordable than fast-fashion retailers, they stock more diverse inventory, and they provide a no-waste shopping experience you can enjoy guilt-free."

The sentence above shows the context of collocation fashion retailers. The context was comparing thrift shops and fast-fashion retailers. As identified before, a thrift shop in this context is a place to shop goods. Therefore, a fashion retailer can be defined as a kind of person or company that sells fashion goods to the public.

11. Brand new

"Someone better call Lady Whistledown, because it looks like there's a brand new couple in the Ton."

The sentence above shows the context of collocation brand new. The context shows something that has never happened before. Therefore, brand new can be defined as totally new.

\section{Each other}

"The Sun is also reporting that Pete and Phoebe are very much interested in each other with a source saying, "Pete is a real charmer and has hit it off with Phoebe, who is obviously beautiful and talented."'" 
It is presented that the sentence above contains a collocation, each other. The collocation of each other in the context above describes something that happened between Pete and Phoebe. So, the meaning of it is to indicate that each person in a group of two people does something to the others.

13. Pretty good

"If you go to the bathroom and your pad is full of blood, that's a pretty good indicator that it's time to switch it out for a new one."

It is presented that the sentence above contains a collocation, pretty good. The collocation pretty good in the context has a function as an indicator for switching a pad. So, the meaning of it is a fairly acceptable standard.

14. Look away

"If you look away from them, it'll make you seem uninterested or signal to your crush that you'd rather be anywhere else."

It is presented that the sentence above contains a collocation, look away. The collocation look away in the context describes an action of someone. So, the meaning of look away is to avoid someone's stare.

15. Bow down

"Honestly, we should all bow down to Hailey Baldwin."

The sentence above shows the context of collocation bow down. The context describes an action of someone to another person. Thus, bowing down means showing respect to someone.

16. Invite over

"Ask them on a study date, go out of your way to talk to them, invite them over for a movie marathon."

The sentence above shows the context of collocation invite over. The context describes some activities that someone can do with other people. Thus, invite over means asking someone to come to your house.

\section{CONCLUSION}

Collocation is one of the important things to learn in English vocabulary. Collocations are important to be studied by EFL Learners and non-native English speakers to make their language sound more natural. The existence of collocations neither has rules nor reasons, and the native speakers use them just because they sound right. Between two types of collocations that exist, this study only analysed one type that is lexical collocations. Analysing the use of lexical collocations is helpful for EFL learners and non-native English speakers to build their vocabulary. Therefore, this study focuses on identifying the use of lexical collocations and their meaning from some texts (website articles) that are written in English from an English-speaking country, seventeen.com.

From eleven articles that were analysed, it is found that 79 lexical collocations were used in the articles. Some of them are used more than once. It is found that there are six out of seven types of collocations used in the articles, they are L1 (verb + noun/pronoun), L3(adjective + noun), L4(noun + verb), L5(noun + noun), L6(adverb + adjective), and L7(verb + adverb). The amount of L1 is twenty collocations, L3 is forty collocations, L4 is one collocation, L5 is seven collocations, L6 is three collocations, and L7 is eight collocations. The meaning of each lexical 
collocations that were found is also being identified. The meaning is defined by looking at the context of the articles. The meaning is added to the comprehension of the lexical collocations so the reader could use the collocations properly.

In short, there are 79 lexical collocations found in some articles on the seventeen.com website. All of them can be classified into six types. The meanings of all of the lexical collocations that are written are also described. By describing the meaning, hopefully, the readers can understand better about lexical collocations.

\section{REFERENCES}

Ashiyan, Z., \& Salehi, H. (2016). Impact of WhatsApp on Learning and Retention of Collocation Knowledge among Iranian EFL Learners. Advances in Language and Literary Studies, 7(5). https://doi.org/10.7575/aiac.alls.v.7n.5p.112

Benson, M., Benson, E., \& Ilson, R. (2010). The BBI Combinatory Dictionary of English: Your guide to collocations and grammar. Third edition revised by Robert Ilson (Third edit). John Benjamins Publishing Company.

Clarke, D. F., \& Nation, I. S. P. (1980). Guessing the meanings of words from context: Strategy and techniques. Topics in Catalysis, 8(3), 211-220. https://doi.org/10.1016/0346251X(80)90003-2

Common Collocation Problems for EFL Learners. (2017). The TEFL Academy. https://www.theteflacademy.com/blog/2017/09/common-collocation-problems-for-efllearners/

Duan, M., \& Qin, X. (2012). Collocation in English teaching and learning. Theory and Practice in Language Studies, 2(9), 1890-1894. https://doi.org/10.4304/tpls.2.9.1890-1894

Galal, M. M. (2015). Lost in Collocation: When Arabic Collocation Dictionaries Lack Collocations. English Language and Literature Studies, 5(2), 18-38. https://doi.org/10.5539/ells.v5n2p18

Gayatri, B. (2018). An Analysis of Collocation in Hillary Clinton 's Speech.

Luis. (2019). English Collocations: All You Need to Know. KSE Academy. https://kseacademy.com/collocations-english/

McCarthy, M. (2018). Why Good Language Teachers Should Take Collocations Seriously. https://www.cambridge.org/elt/blog/2018/01/04/why-good-language-teachers-should-takecollocations-seriously/

McCarthy, M., \& O’Dell, F. (2005). English Collocations in Use. Cambridge.

McIntosh, C., Francis, B., \& Poole, R. (Eds.). (2002). Oxford Collocations Dictionary for Students of English. Oxford University Press.

Oliveira, S. (2013). 1000 English Collocations in 10 Minutes a Day. EspressoEnglish.net.

Palmer, C., \& Bolderston, A. (2006). A Brief Introduction to Qualitative Research. Canadian Journal of Medical Radiation Technology, 37(1), 16-19. https://doi.org/10.1016/s08205930(09)60112-2

Putri, R. (2018). An Analysis of Collocations Used in Written Assignment.

Rakhmawati, A. (2017). Lexical Collocation in The Jakarta Post Newspaper. 23-24.

Rini, R., \& Moehkardi, D. (2002). Grammatical and Lexical English Collocations: Some Possible Problems to Indonesian Learners of English. 14(1), 53-62. 
Roell, K. (2020). Understanding Vocabulary Words in Context. ThoughtCo. https://www.thoughtco.com/understanding-vocabulary-words-in-context-3211741

Yan, H. (2010). Study on the Causes and Countermeasures of the Lexical Collocation Mistakes in College English. English Language Teaching, 3(1), 162-165. https://doi.org/10.5539/elt.v3n1p162 